\title{
Role of coral-derived chemical cues in microhabitat selection by settling Chromis viridis
}

\author{
O. Ben-Tzvi ${ }^{1,2, *}$, D. Tchernov ${ }^{1,3,4}$, M. Kiflawi ${ }^{1,2}$ \\ ${ }^{1}$ The Interuniversity Institute for Marine Sciences in Eilat, POB 469, Eilat 88103, Israel \\ ${ }^{2}$ Department of Life Sciences, Ben-Gurion University of the Negev, Be'er Sheva 84105, Israel \\ ${ }^{3}$ Department of Evolution, Systematics and Ecology, The Hebrew University of Jerusalem, Edmond J. Safra - Givat-Ram, \\ Jerusalem 91904, Israel \\ ${ }^{4}$ Marine Biology Department, The Leon H. Charney School of Marine Sciences, Haifa University, Haifa, Israel
}

\begin{abstract}
Insight into the mechanisms that underlie settlement and recruitment is important for our understanding of the demography and ecology of coral reef fish and the biology of their coral host. Current knowledge of larval behaviour leading up to settlement is rather meager, and is mostly derived from controlled experiments under artificial conditions. However, it has been shown that presettlement juvenile fishes use acoustic and olfactory cues to locate the reef and, together with visual cues, to choose their first habitat in the reef. Chromis viridis (Pomacentridae) also use chemical and physical cues to locate the coral colonies on which they settle. Moreover, they appear to consistently and preferentially utilize some, but not other, conspecific colonies. To further evaluate the cues involved in microhabitat choice at settlement, we used in situ manipulation in which water from Acropora spp. coral colonies with positive settlement histories (SH+) was transferred to colonies with negative settlement histories ( $\mathrm{SH}-$ ) and vice versa. By closely monitoring settlement to manipulated and non-manipulated colonies, we found that at least 2 different water-borne cues are informing micro-habitat selection by $C$. viridis. Water transferred from $\mathrm{SH}-$ to $\mathrm{SH}+A$. hyacintus colonies was found to discourage settlement in the $\mathrm{SH}+$ colonies. On the other hand, water transferred from $\mathrm{SH}+$ to $\mathrm{SH}-$ A. eurystoma colonies encouraged settlement in the $\mathrm{SH}$-colonies. These findings show that dissolved coral-derived cues dictate the fishes' settlement decisions, which raises an intriguing question as to the information content of these cues and their evolutionary context.
\end{abstract}

KEY WORDS: Settlement · Coral reef fish · Odour

Resale or republication not permitted without written consent of the publisher

\section{INTRODUCTION}

Almost all coral reef fishes undergo a dispersive pelagic larval stage before settling onto the reef and recruiting to the adult population. Following settlement, some fishes will undergo metamorphosis and grow before they recruit to the site they will occupy for the rest of their life. Other fishes, including many damselfish (Pomacentridae), metamorphose prior to settlement and settle directly to the adult habitat (McCormick \& Makey 1997). For these fishes, patterns set at settlement stand to have lingering effects on the spatial distribution of local abundance and species richness. Although post-settlement processes such as competition (Jones 1991), predation (Carr \& Hixon 1995) and migration (Ben-Tzvi et al. 2008) can have a modifying role, initial habitat selection remains a key factor for further success (Hixon \& Beets 1993, Sponaugle \& Cowen 1996).

Cues that can inform settlement operate at different spatial scales. Reef-derived acoustic (Leis et al. 2002, Egner \& Mann 2005, Simpson et al. 2005, Wright et al. 2005), visual (Leis \& Carson-Ewart 1999) and chemical cues (Atema et al. 2002, Gerlach et al. 2007, Dixson et al. 2008, 2010) can aid in the detection of, and orientation towards, the reef from the open sea and in locating suitable habitats at the reef. At a closer range, while the fish are already on the reef, chemical cues may also 
aid in identifying and locating conspecifics (Sweatman 1988, Lecchini et al. 2005a,b).

In a previous study (Ben-Tzvi et al. 2008), we have shown that settling Chromis viridis (Cuvier) prefer to settle with conspecific adults within Acropora spp. colonies (see also Lecchini et al. 2005b). However, not all colonies housing adults received settlers, whereas some colonies that were not inhabited by adults did receive settlers. This may not be surprising if it was not for the fact that the same colonies were consistently selected or rejected over 2 major settling events in 2004 and 2005. Although these data suggest that settling with conspecifics may not be as important as originally thought, it is not clear what drives $C$. viridis settlers to prefer specific colonies (whether inhabited by conspecifics or not) over others.

Scleractinian corals are known to be a critical settlement habitat for many coral reef fishes, of which many are not strictly coral-dependent as adults (Jones et al. 2004, Wilson et al. 2006, Pratchett et al. 2008). Thus it is important to understand why fish select specific coral colonies and not others. Since no physical parameters were found to explain the pattern of colony selection or rejection (e.g. colony size and location; BenTzvi et al. 2008), we turned our attention to less obvious factors. In the present study, we tested the hypothesis that a chemical cue emitted from the habitat is responsible for the differences found in settlement histories of Acropora spp., with Chromis viridis as the model fish species.

\section{MATERIALS AND METHODS}

Study site. The present study was conducted on a sparse reef ( 15 to $20 \%$ hard coral live cover) located in the northwestern tip of the Gulf of Aqaba (Red Sea) and composed mainly of several species of branching corals. Schools of Chromis viridis are abundant at the study site at depths of 1 to $10 \mathrm{~m}$, and are found mainly in 2 Acropora species: A. eurystoma and A. hyacintus, with a preference for the former (Ben-Tzvi et al. 2008). Settlement of $C$. viridis in the northern Gulf may occur from late May to February, in discrete events of different durations (10 to $45 \mathrm{~d}$ ) separated by periods of similarly varying durations (Ben-Tzvi et al. 2007, 2008). Although some $C$. viridis settle directly to their final habitat and should be considered recruits (McCormick \& Makey 1997), we will use the term settlement since some of the settlers migrate a few weeks after settlement to another habitat that might become their final habitat (Ben-Tzvi et al. 2008).

Site history. During 2007 we monitored (3 times per week) the number of Chromis viridis that settled onto 70 tagged colonies of Acropora eurystoma and A. hyacintus, of which $54 \%$ were inhabited by adult conspecifics (Table 1; for details see Ben Tzvi et al. 2008). These data served to establish the settlement history of these colonies, which was verified during the first settlement event of 2008. These colonies also served as the basis for the manipulative experiment described in the next subsection. Settlement into the same colonies was also monitored during 2009.

Experimental design. Conspecific Acropora colonies were paired according to settlement history and adult occupancy, such that colonies with positive settlement history $(\mathrm{SH}+)$ were always paired with colonies of negative history ( $\mathrm{SH}-$ ) (see Table 3 ). One of the colonies in the pair was used as the source of the putative chemical cue and the other as the target which received the cue (i.e. source colony $=$ colony from which water was taken; target colony $=$ colony to which water was delivered). An aquarium circulation pump (Atman Liquid Filter AT-2001) was used to transport water from the source to the target at a rate of $1 \mathrm{l} \mathrm{h}^{-1}$ (the experimental design is detailed in Fig. 1). The pump was situated $1.5 \mathrm{~m}$ away from the source coral and fed by an inlet pipe ending at the centre of the colony. The $2 \mathrm{~mm}$ internal diameter PVC outlet pipe, whose length controlled the flow rate, delivered the pumped water to the centre of the target colony. Except for the water transport we did not change any parameter; the colonies were not relocated and their inhabitant stayed in the colony. Preliminary trials using fluorescein dye established that the residence time of the pumped water within the target colonies was $>30 \mathrm{~min}$.

With one exception, colonies were paired during periods of little or no settlement (Ben-Tzvi et al. 2007). Paired colonies were monitored daily until the end of the subsequent settlement event (see Table 2 for details) or until all SH-targets received settlement due to manipulation. Settlement event E2-08 was long enough for us to run 2 successive manipulations (see

Table 1. Chromis viridis, Acropora eurystoma and A. hyacintus. Presence of existing adult $C$. viridis (+: present; -: absent) and settlement histories (+: positive; -: negative) of the experimental Acropora colonies at the beginning of the experiment

\begin{tabular}{|lccc|}
\hline Coral species & $\begin{array}{c}\text { Adult } \\
\text { presence }\end{array}$ & $\begin{array}{c}\text { Settlement } \\
\text { history }\end{array}$ & $\begin{array}{c}\text { No. of } \\
\text { colonies }\end{array}$ \\
\hline Acropora eurystoma & + & + & 22 \\
& + & - & 5 \\
& - & + & 6 \\
Acropora hyacintus & - & - & 19 \\
& + & + & 4 \\
Total & + & - & 7 \\
& - & + & 2 \\
& - & & 70 \\
\hline
\end{tabular}




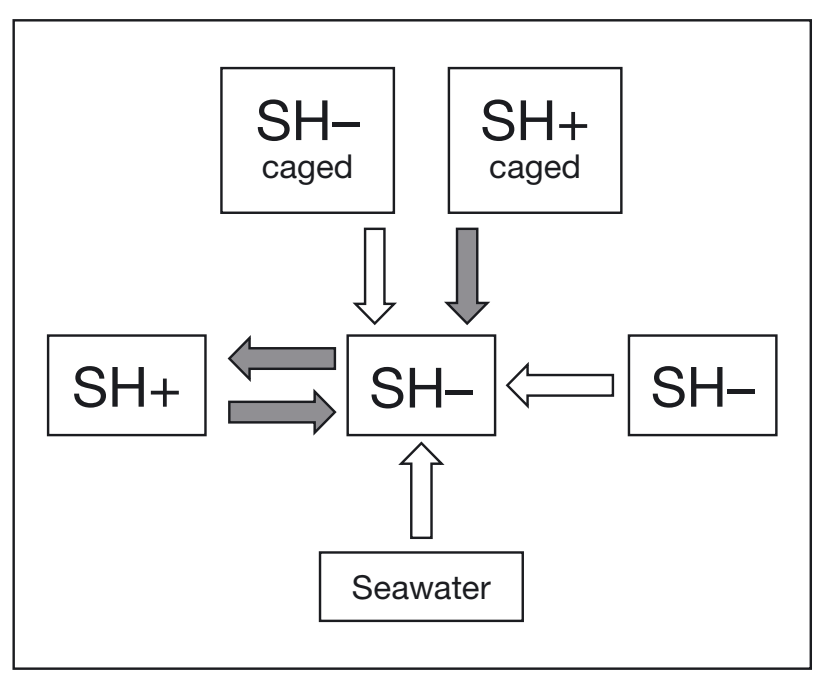

Fig. 1. Design of the experiment with Acropora eurystoma colonies. Arrows indicate the directions of transported water from different source colonies to target colonies (white arrows are controls). Number of replicates is shown in Table 3. SH: settlement history; -: negative; +: positive

Fig. 2). We continued the daily monitoring of the target colonies 1 wk after the pumps were stopped to document whether the induced change in settlement to these colonies was reversible. Some colonies were used in more than one trial, but never as part of the same pair.

The results obtained from the experiment with pairs of Acropora eurystoma demonstrated clearly that there is a dissolved attractant extracted by the selected colonies and/or all their associated creatures (see 'Results'). Since juvenile Chromis viridis release a protein that attracts settlement by conspecifics (Lecchini et al. 2005b), it was essential to circumvent this potentially confounding effect. To do so, 4 source colonies were cleared (using clove oil) of their inhabitants prior to the fourth settlement event. To prevent recolonization, these colonies were covered with a dense plastic mesh (1 mm mesh size), which was cleaned regularly to prevent fouling. To maintain the health of these colonies, a second pump was used to maintain proper water exchange with the ambient. Settlers were removed daily from the target colonies to prevent their effect on subsequent settlement.

To verify our results we ran 2 controls. First, 2 SHAcropora eurystoma colonies received water pumped from the water column adjacent to a colony that previously served as a $\mathrm{SH}+$ source (i.e. the inlet pipe was placed $\sim 50 \mathrm{~cm}$ from the colony and at the same height above the substrate). This water is assumed to contain highly reduced concentrations of the putative chemical cue. Second, a pair of SH-A. eurystoma colonies that were settled when paired as target colonies with $\mathrm{SH}+$ colonies were paired a second time as target colonies but with $\mathrm{SH}$ - colonies.

Colonies not included (tagged unpaired colonies) in the experiment were monitored 3 times per week. We did not consider data from one settlement event (see below) in which only $38 \%$ of the $\mathrm{SH}+$ colonies received settlement because of the low overall probability of settlement. For A. eurystoma, we had 15 replications of $\mathrm{SH}+$ to $\mathrm{SH}-$ and 3 of $\mathrm{SH}-$ to $\mathrm{SH}+$ (controls excluded). For $A$. hyacintus we had 3 replications of each direction (see Table 3).

Data analysis. We used a Fisher's exact test to examine whether the manipulation brought about a significant change in the settlement of target Acropora eurystema colonies with a negative settlement history (SH-, Table 1) beyond that observed in unmanipulated colonies. We ran a separate analysis for each settlement event, using manipulated and unmanipulated SH-colonies as independent observations and disregarding occupancy by conspecific adults. We ran an additional analysis of the 3 colony pairs where the source was covered and the settlers were removed daily. In this analysis we used settlement days as independent observations, since the target colony was in its initial empty state each day (i.e. out of a total of 24 possible days: 3 colonies $\times$ the duration of the event; settlement to unmanipulated $\mathrm{SH}$ - colonies was scored out of $19 \times 8=152$ d). We also used Fisher's exact test to examine whether, in A. hyacintus, source type ( $\mathrm{SH}-$ or $\mathrm{SH}+$ ) had an effect on settlement to a target of the opposite type (see Table 3). In this case, however, we pooled data from the 3 settlement events during which the manipulation was performed (i.e. the same $6 \mathrm{SH}+$ colonies were considered in each event, but each time using a different colony for the manipulation).

Complementary data. In addition, we used data which were collected on the settlement of fishes during 2007-2009 in the same tagged colonies. These data include settlement of different species of fishes in these colonies and mortality of coral colonies as a result of predation by Drupella sp. snail (these are gradual mortalities which can last from several weeks to a few months depending on the colony's size and the number of snails; the snails are easily observed at the edges of the dead area). Similar data on fish settlement and coral mortality were collected during 2003-2005 using the same methods (Ben-Tzvi et al. 2007, 2008, 2009).

\section{RESULTS}

Five events of Chromis viridis settlement occurred during the entire settlement season in 2008 (E1 to E5, Table 2). Of the 36 colonies classified as SH- in 2007 , between 83 and $100 \%$ received no settlement during 
Table 2. Chromis viridis. Summary of $C$. viridis settlement to the tagged coral colonies during and at each recruitment event in 2008 (E1 to E5). Duration refers to the number of days during which pumps were deployed, which may be shorter than the event itself. Total and daily average number of settlers documented in tagged colonies during the experiment period (= duration) is also shown

\begin{tabular}{|lccc|}
\hline Event & $\begin{array}{c}\text { Duration } \\
(\mathrm{d})\end{array}$ & $\begin{array}{c}\text { Settlers total } \\
(\mathrm{n})\end{array}$ & $\begin{array}{c}\text { Daily average } \\
\left(\text { no. d }^{-1}\right)\end{array}$ \\
\hline E1-08 & 20 & 403 & 20.2 \\
E2-08a & 18 & 423 & 23.5 \\
E2-08b & 4 & 90 & 22.5 \\
E3-08 & 24 & 33 & 1.4 \\
E4-08 & 10 & 1991 & 199.1 \\
E5-08 & 8 & 299 & 37.4 \\
\hline
\end{tabular}

each of these 5 events. All $\mathrm{SH}$ - colonies that received settlement were target colonies, except for 2 nonmanipulated colonies during E4 (Table 3). On the other hand, of the 34 colonies classified as $\mathrm{SH}+$, between 94 and $100 \%$ were resettled during 4 of the 5 settlement events (Fig. 2). E3 was ignored because of the low settlement rate (only $38 \%$ of $\mathrm{SH}+$ colonies were resettled; Fig. 2).

Importantly, settlers of other pomacentrid species as well as those of many other families (e.g. Chaetodonti-

Table 3. Pairs used for manipulation of the water in the inner volume of the target coral. A+/-: presence/absence of Chromis viridis adults; $\mathrm{SH}+$ /-: positive/negative $C$. viridis settlement history; In parentheses: number of caged previously selected source colonies. Switches are changes in the target colony status (between selected and unselected by the settling fish) within the period that the pump was deployed. Categories are as follows: 1: from $\mathrm{SH}+$ to $\mathrm{SH}-$ Acropora eurystoma colonies; 2 : from $\mathrm{SH}$ - to $\mathrm{SH}+A$. eurystoma colonies; 3 ; from $\mathrm{SH}+$ to $\mathrm{SH}-\mathrm{A}$. hyacintus colonies; 4 : from $\mathrm{SH}$ - to $\mathrm{SH}+$ A. hyacintus colonies; and C: control

\begin{tabular}{|c|c|c|c|c|}
\hline $\begin{array}{l}\text { Coral species } \\
\text { and category }\end{array}$ & Source & Target & Replicates & Switch \\
\hline \multicolumn{5}{|c|}{ Acropora eurystoma } \\
\hline \multirow[t]{4}{*}{1} & $\mathrm{~A}+\mathrm{SH}+$ & $\mathrm{A}-\mathrm{SH}-$ & $4(1)$ & 3 \\
\hline & $\mathrm{A}+\mathrm{SH}+$ & $\mathrm{A}+\mathrm{SH}-$ & $9(2)$ & 9 \\
\hline & $\mathrm{A}-\mathrm{SH}+$ & $\mathrm{A}+\mathrm{SH}-$ & 2 & 2 \\
\hline & Total & & 15 & 14 \\
\hline \multirow[t]{3}{*}{2} & $\mathrm{~A}+\mathrm{SH}-$ & $\mathrm{A}+\mathrm{SH}+$ & 1 & 0 \\
\hline & $\mathrm{A}-\mathrm{SH}-$ & $\mathrm{A}+\mathrm{SH}+$ & 2 & 0 \\
\hline & Total & & 3 & 0 \\
\hline \multirow[t]{4}{*}{$\mathrm{C}$} & $\mathrm{A}+\mathrm{SH}-$ & $\mathrm{A}+\mathrm{SH}-$ & $2(1)$ & 0 \\
\hline & Seawater & $\mathrm{A}+\mathrm{SH}-$ & 1 & 0 \\
\hline & Seawater & $\mathrm{A}-\mathrm{SH}-$ & 1 & 0 \\
\hline & Total & & 4 & 0 \\
\hline \multicolumn{5}{|c|}{ Acropora hyacintus } \\
\hline 3 & $\mathrm{~A}+\mathrm{SH}+$ & $\mathrm{A}+\mathrm{SH}-$ & 3 & 0 \\
\hline 4 & $\mathrm{~A}+\mathrm{SH}-$ & $\mathrm{A}+\mathrm{SH}+$ & 3 & 3 \\
\hline
\end{tabular}

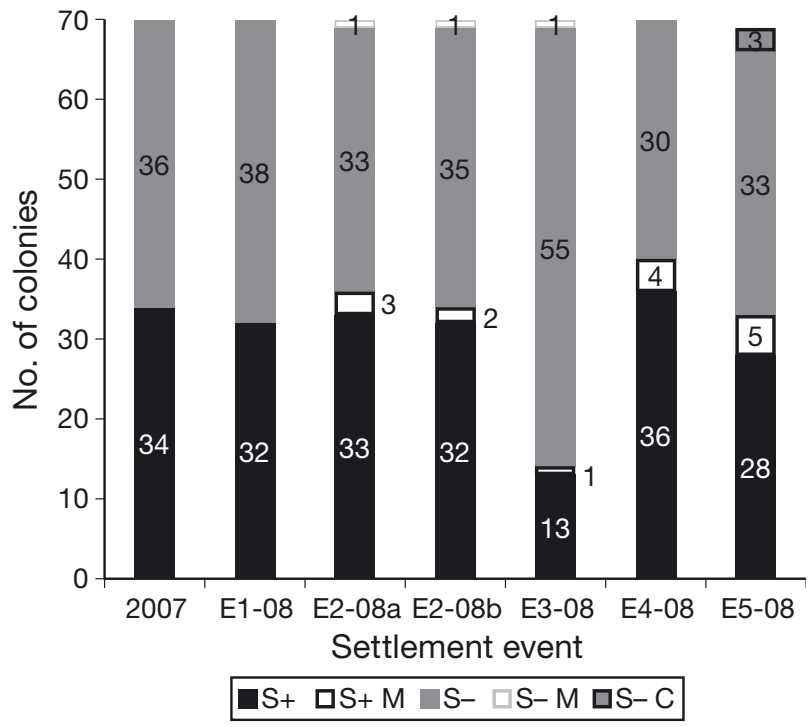

Fig. 2. Chromis viridis, Acropora hyacintus and A. eurystoma. Settlement of $C$. viridis to the tagged coral colonies during the entire season of 2007 and at each settlement event in 2008 (E1 to E5). The experiment started following E1. E2 is divided into 2 because we redeployed the pumps during this event. Numbers in columns are the number of colonies of each category. Categories are: S+: colonies in which settlement was documented; S+ M: manipulated SH- A. hyacintus colonies in which settlement was documented; $\mathrm{S}-$ : colonies with no settlement; $\mathrm{S}-\mathrm{M}$ : manipulated $\mathrm{SH}+A$. eurystoma colonies in which settlement was prevented; $\mathrm{S}-\mathrm{C}$ : covered $A$. hyacintus source colonies in which settlement was prevented. Total number of colonies is 70 except for E5 which occurred after 2 colonies were predated on by Drupella sp.

dae, Scoraenidae, Serranidae, Ephippidae, Labridae, Acanthuridae and Scaridae) were observed in the same colonies settled by Chromis viridis, but were absent from colonies ignored by $C$. viridis. One exception is Dascyllus marginatus, which in intensive settlement events spreads in almost all branching colonies. However when fewer settlers of the species arrived they settled into the same preferred colonies as other fishes.

We have documented 2 different effects of the manipulation. (1) For Acropora hyacintus, settlement of $\mathrm{SH}+$ colonies discontinued upon receiving water from $\mathrm{SH}$ - colonies $(\mathrm{p}=0.001$; category 4 in Table 3$)$, whereas water from $\mathrm{SH}+$ colonies did not induce settlement on target SH- colonies (category 3). (2) For A. eurystoma, settlement on $\mathrm{SH}$ - colonies was induced by water emanating from $\mathrm{SH}+$ colonies (category 1 in Table 3; Table 4). Water from SH- colonies did not affect settlement on $\mathrm{SH}+$ colonies (category 2). For the covered colony-pairs examined during E5, water transfer from $\mathrm{SH}+$ to $\mathrm{SH}$ - colonies significantly altered the settlement pattern of the targets: they received settle- 
Table 4. Chromis viridis and Acropora eurystoma. Summary of the results of induced changes in manipulated $A$. eurystoma colonies with negative settlement history (category 1 in Table 3 ) compared with non-manipulated $\mathrm{SH}-A$. eurystoma colonies. Each row provides the data for one round of the experiment including the probability (p) of obtaining the observed distribution of $C$. viridis settlers in previously unselected corals as obtained by Fisher's exact test. Presented are the numbers of SH-colonies. In parentheses the number of caged

$\mathrm{SH}+$ A. eurystoma colonies which served as source in this specific event

\begin{tabular}{|lcccccr|}
\hline \multirow{2}{*}{ Event } & \multicolumn{2}{c}{ Manipulated } & & \multicolumn{2}{c|}{ Unmanipulated } & $p$ \\
& Settlement & No settlement & Settlement & No settlement & \\
\hline E2a & 3 & 0 & 0 & 21 & $<0.001$ \\
E2b & 2 & 1 & 0 & 21 & 0.011 \\
E4 & 3 & 0 & 0 & 21 & $<0.001$ \\
E5 & $5(3)$ & 0 & 0 & 19 & $<0.001$ \\
\hline
\end{tabular}

tlement of Chromis viridis and other fishes was documented in $33(21.7 \%)$ of these colonies. During these observations we documented 13 colonies that were preyed upon by the coral predator snail Drupella sp. All the preyed colonies were $\mathrm{SH}+$ colonies $(39.4 \%$ of these colonies). Four of these attacks had started prior to the beginning of settlement (but settlement was observed before the coral colony was completely dead) while all others began when the coral was already occupied. At the same time, $7.1 \%$ of $\mathrm{SH}-A$. eurystoma and $6.8 \%$ of $\mathrm{SH}+A$. eurystoma were attacked by Drupella sp.

\section{DISCUSSION}

$152 \mathrm{~d}$ in non-manipulated $\mathrm{SH}$ - colonies ( $\mathrm{p}=0.001)$.

Induced changes in settlement, whether positive or negative, were found to be reversible. At the end of each round, when we stopped the pumps, all settlers on target SH- Acropora eurystoma colonies disappeared within 1 or $2 \mathrm{~d}$, with the exception of a single individual. Moreover, during E5, a group of about 50 juveniles migrated to one of the target $\mathrm{SH}-A$. eurystoma colonies. Once the water flow from the uncaged source was stopped, these fish left together with those that had settled during the experiment. Similarly, the induced prevention of settlement on target $\mathrm{SH}+$ A. hyacintus colonies was terminated once pumping from the source was stopped, with fish settling on the ex-target either within a settlement event (E2a) or at the beginning of the subsequent event (E3 and E4).

Mechanical failure of the pumps provided several unplanned observations that were consistent with the patterns already described. On 2 occasions, settlement to target SH+Acropora hyacintus colonies began once the flow from the source ceased, only to stop again once the flow of water from the $\mathrm{SH}$ - colonies was re-established. At that point, those individuals that had settled on the $\mathrm{SH}+$ targets emigrated away from the corals.

The settlement pattern described above for 2007 and 2008 was mirrored in 2 prolonged and very intensive settlement events of 2009. Namely, all surviving SH+ colonies of both Acropora species were resettled by Chromis viridis, whereas all but one $\mathrm{SH}-$ colony remained unsettled. These include the $3 \mathrm{SH}+$ colonies from which all resident fish were removed. Two were resettled by adults during the winter of 2008-9 while the third stayed empty from $C$. viridis until the first settlers arrived.

During 2003-2009 we monitored the settlement to 152 tagged Acropora hyacintus colonies (each colony was monitored for at least 8 mo and for up to 4 yr). Set-
It is becoming increasingly clear that coral reef fish larvae can actively affect their dispersal. At relatively large spatial scales, pre-settlement juveniles may use acoustic (Leis et al. 2002, Tolimieri et al. 2004) and chemical cues (Atema et al. 2002, Gerlach et al. 2007) to locate and orient towards the reef onto which they settle. Once at the reef, settlers may preferentially choose specific coral colonies over others, using various sensory modalities (Sweatman 1988, Lecchini et al. 2005a,b, Ben-Tzvi et al. 2008). Microhabitat selection is to be expected when a relation exists between colony attributes and settler survival rates. The presence of conspecifics may contribute to reduced aggression from adults; additional settlers may contribute to a dilution effect (Krebs \& Davies 1987) and settlers may gain better predator recognition (Karplus et al. 2006). Our findings that chemical cues, which are derived from the coral itself and/or its associated non-piscine fauna and/or flora, repeatedly encourage or discourage settlement are especially intriguing as the evolutionary motivation is not apparent.

Chromis viridis settle on colonies of different coral species based on availability and abundance, but utilize a non-random sub-sample of the available conspecific colonies (e.g. Lecchini et al. 2007, Ben-Tzvi et al. 2008). Our results provide evidence that this apparent selection is based on water-borne cues emanating from the inner volume of the coral. We have also shown that more than a single chemical cue may be involved in informing the settlers. In one coral species (Acropora eurystoma) the cue was found to be an attractant, while in another (A. hyacintus) it was found to be a repellent. These cues are used similarly by settling fishes of different families. Moreover, in Guam and in the Philippines, settlers of several species, including 
pomacentrids, chaetodontids, labrids, scarids and serranids, were observed in only a few colonies of Porites rus, P. cylindrica and Acropora spp. out of many more colonies of these species in which no settlers were observed (O. Ben-Tzvi unpubl. data). These observations indicate that such discrimination between corals of the same species is widespread even though it is not known whether the cue is a repellent or an attractant in other species. The temporal consistency in the response to specific colonies (see also Ben-Tzvi et al. 2008), as well as its apparent generality among fish species and geographic location, suggests that the information conveyed by the cue(s) may relate to future prospects and not just immediate conditions. However, juvenile and adult $C$. viridis are known, at times, to emigrate away from their initial settlement sites and occupy SH-colonies (Ben-Tzvi et al. 2008). This would seem to suggest a short-term benefit to microhabitat selection and/or the loss of sensitivity to the chemical cue.

Gerlach et al. (2007) suggested that in some benthicspawning fish species, developing larvae might become imprinted on chemical cues that could later guide their settlement onto their natal reef. Similar imprinting to specific coral-colony 'types' (presumably while still within the egg) will generate a self-reinforcing pattern of settlement that, as mentioned above, may or may not extend into the pattern of adult distribution within the reef (Ben Tzvi et al. 2008). Imprinting to cues that inform of the location of a reef can be advantageous as the failure to find a reef is fatal (Gerlach et al. 2007). However, the benefits for imprinting on specific colony types, and how it may come about, are less obvious for several reasons: (1) several coral dwelling damselfishes in our study area do not settle only with conspecific adults (Ben-Tzvi et al. 2008, 2009); (2) Chromis viridis spawns on bare rock and dead corals away from their coral colony (Thresher 1984), so eggs are unlikely to be exposed to the putative cue; (3) settlers of fish species with pelagic eggs have been documented to preferentially utilize the same $\mathrm{SH}+$ coral colonies as $C$. viridis; and (4) mechanistically, imprinting on repellents seems problematic

Chromis viridis utilizes a variety of coral species across its circumtropical distribution (e.g. Lecchini et al. 2007, Ben-Tzvi et al. 2008, present study), presumably as a function of coral availability. The choices made by pre-settlement larvae may thus represent a response to cues that are not directly dependent on the taxonomic affiliation of the coral colony and which differ between corals of the same species. An example would be cues that emanate from the bacterial fauna that lives in association with corals (the coral holobiont; Rosenberg et al. 2007), which are known to vary across colonies (Rohwer et al. 2002). Such cues may be shared by various fish species that use coral colonies as nurseries, across a wide geographic scope. If imprinting were indeed unlikely as we suggest, then these cues and the (hard-wired) response to them would seem to be of deep evolutionary origin.

A cue that informs a variety of fish species and is shared by various coral species is intriguing, as it may be an adaptive trait of the coral, the benefit of which is accrued due to the response of the fish. On the one hand, there is a possibility that some coral colonies are eliciting settlement in order to accrue benefits afforded by resident fish (Goldshmid et al. 2004). It was suggested that the coral colony's hologenome has a major role in increasing the coral fitness by enhancement of its resistance to diseases (Rosenberg et al. 2007). It might be that here we are witnessing one more way in which the hologenome increases the corals' fitness as well as that of the settling fishes This explanation may suit the case shown here for Acropora eurystoma. On the other hand, as shown for $A$. hyacintus, the repellent that prevents fish from settling in some of the colonies (whether it is extracted by the coral itself or by other component of the holobiont) may protect these colonies from being preyed upon by the Drupella sp. snail. It is not known yet whether it is a repellant or an attractant causing the discrimination between corals of different species. This aspect, the active agents and the benefits for the fish are subjects for further research.

Knowledge of the mechanisms that govern the settlement of suitable habitats is crucial to understanding the population biology, community dynamics and evolution of coastal marine organisms (Caley et al. 1996). It is also critical for informed management and conservation efforts. Pollutants may interfere with waterborne cues, with far-reaching effects even when not detrimental to the organism itself (Lurling \& Scheffer 2007). Moreover, the ability of settling fishes to discriminate between chemical cues and use the correct signals for homing and habitat selection is endangered by ocean acidification (Munday et al. 2009). Understanding the chemical nature of the cues involved in settlement, their source and the potential benefit of responding to them is an important future step.

Acknowledgements. This study was supported by an Israel Science Foundation (ISF) grant to M.K. (grant no. 286/06), a Boxenbaum-Neta Foundation grant to O.B. and an ISF grant (no. 981/05) to D.T. We thank the management and staff of the Interuniversity Institute for Marine Sciences in Eilat for their cooperation and help. K. Levi, O. Polak and many others helped in the daily dives needed for this study. M. Hohevya prepared all the equipment used in the study. We thank the Israel Nature and Parks Authority staff of Eilat for their cooperation. The authors thank 4 anonymous reviewers for their constructive criticisms. 


\section{LITERATURE CITED}

Atema J, Kingsford MJ, Gerlach G (2002) Larval reef fish could use odour for detection, retention and orientation to reefs. Mar Ecol Prog Ser 241:151-160

Ben-Tzvi O, Kiflawi M, Gildor H, Abelson A (2007) Possible effects of downwelling on the recruitment of coral reef fishes to the Eilat (Red Sea) coral reefs. Limnol Oceanogr 52:2618-2628

Ben-Tzvi O, Abelson A, Polak O, Kiflawi M (2008) Habitat selection and the colonization of new territories by Chromis viridis. J Fish Biol 73:1005-1018

Ben-Tzvi O, Kiflawi M, Polak O, Abelson A (2009) The effect of adult aggression on habitat selection by settlers of two coral-dwelling damselfishes. PLoS ONE 4:e5511 doi: 10. 1371/journal.Pone.0005511

Caley MJ, Carr MH, Hixon MA, Hughes TP, Jones GP, Menge BA (1996) Recruitment and the local dynamics of open marine populations. Annu Rev Ecol Syst 27:477-500

Carr MH, Hixon MA (1995) Predation effects on early postsettlement survivorship of coral-reef fishes. Mar Ecol Prog Ser 124:31-42

Dixson DL, Jones GP, Munday PL, Planes S and others (2008) Coral reef fish smell leaves to find island homes. Proc R Soc Lond B 275:2831-2839

Dixson DL, Munday PL, Jones GP (2010) Ocean acidification disrupts the innate ability of fish to detect predator olfactory cues. Ecol Lett 13:68-75

Egner SA, Mann DA (2005) Auditory sensitivity of sergeant major damselfish Abudefduf saxatilis from post-settlement juvenile to adult. Mar Ecol Prog Ser 285:213-222

Gerlach G, Atema J, Kingsford MJ, Black KP, Miller-Sims V (2007) Smelling home can prevent dispersal of reef fish larvae. Proc Natl Acad Sci USA 104:858-863

Goldshmid R, Holzman R, Weihs D, Genin A (2004) Aeration of corals by sleep-swimming fish. Limnol Oceanogr 49: $1832-1839$

Hixon MA, Beets JP (1993) Predation, prey refuges, and the structure of coral-reef fish assemblages. Ecol Monogr 63: $77-101$

Jones GP (1991) Post recruitment processes in the ecology of coral reef fish populations: a multifunctional perspective. In: Sale PF (ed) The ecology of fishes on coral reefs. Academic Press, San Diego, CA, p 294-328

Jones GP, McCormick MI, Srinivasan M, Eagle JV (2004) Coral decline threatens fish biodiversity in marine reserves. Proc Natl Acad Sci USA 101:8251-8253

Karplus I, Katzenstein R, Goren M (2006) Predator recognition and social facilitation of predator avoidance in coral reef fish Dascyllus marginatus juveniles. Mar Ecol Prog Ser 319:215-223

Krebs JR, Davies NB (1987) An introduction to behavioral ecology. Blackwell Scientific Publications, Oxford

Lecchini D, Planes S, Galzin R (2005a) Experimental assessment of sensory modalities of coral-reef fish larvae in the recognition of their settlement habitat. Behav Ecol Sociobiol 58:18-26

Editorial responsibility: Pei-Yuan Qian, Kowloon, Hong Kong SAR
Lecchini D, Shima J, Banaigs B, Galzin R (2005b) Larval sensory abilities and mechanisms of habitat selection of a coral reef fish during settlement. Oecologia 143: 326-334

Lecchini D, Planes S, Galzin R (2007) The influence of habitat characteristics and conspecifics on attraction and survival of coral reef fish juveniles. J Exp Mar Biol Ecol 341: 85-90

> Leis JM, Carson-Ewart BM (1999) In situ swimming and settlement behaviour of larvae of an Indo-Pacific coral-reef fish, the coral trout Plectropomus leopardus (Pisces: Serranidae). Mar Biol 134:51-64

Leis JM, Carson-Ewart BM, Cato DH (2002) Sound detection in situ by the larvae of a coral-reef damselfish (Pomacentridae). Mar Ecol Prog Ser 232:259-268

Lurling M, Scheffer M (2007) Info-disruption: pollution and the transfer of chemical information between organisms. Trends Ecol Evol 22:374-379

- McCormick MI, Makey LJ (1997) Post-settlement transition in coral reef fishes: overlooked complexity in niche shifts. Mar Ecol Prog Ser 153:247-257

- Munday PL, Dixson DL, Donelson JM, Jones GP, Pratchett MS, Devitsina GV, Doving KB (2009) Ocean acidification impairs olfactory discrimination and homing ability of a marine fish. Proc Natl Acad Sci USA 106:1848-1852

Pratchett MS, Munday PL, Wilson SK, Graham MH and others (2008) Effects of climate-induced coral bleaching on coralreef fishes: ecological and economic consequences. Oceanogr Mar Biol Annu Rev 46:251-296

Rohwer F, Seguritan V, Azam F, Knowlton N (2002) Diversity and distribution of coral-associated bacteria. Mar Ecol Prog Ser 243:1-10

Rosenberg E, Koren O, Reshef L, Efrony R, Zilber-Rosenberg I (2007) The role of microorganisms in coral health, disease and evolution. Nat Rev Microbiol 5:355-362

Simpson SD, Meekan M, Montgomery J, McCauley R, Jeffs A (2005) Homeward sound. Science 308:221

Sponaugle S, Cowen RK (1996) Larval supply and patterns of recruitment for two Caribbean reef fishes, Stegastes partitus and Acanthurus bahianus. Mar Freshw Res 47: 433-447

Sweatman HPA (1988) Field evidence that settling coral-reef fish larvae detect resident fishes using dissolved chemical cues. J Exp Mar Biol Ecol 124:163-174

Thresher RE (1984) Reproduction in reef fishes. T. F. H Publications, Neptune City, NJ

- Tolimieri N, Haine O, Jeffs A, McCauley R, Montgomery J (2004) Directional orientation of pomacentrid larvae to ambient reef sound. Coral Reefs 23:184-191

- Wilson SK, Graham NAJ, Pratchett MS, Jones GP, Polunin NVC (2006) Multiple disturbances and the global degradation of coral reefs: Are reef fishes at risk or resilient? Glob Change Biol 12:2220-2234

Wright KJ, Higgs DM, Belanger AJ, Leis JM (2005) Auditory and olfactory abilities of pre-settlement larvae and postsettlement juveniles of a coral reef damselfish (Pisces: Pomacentridae). Mar Biol 147:1425-1434

Submitted: November 4, 2009; Accepted: April 1, 2010

Proofs received from author(s): June 5, 2010 